Genome Québec Innovation Centre. Bossé has found that mice bred without the vitamin D receptor fail to develop experimental allergic asthma.

Researchers are particularly keen to study the gene and environment interaction, which will likely provide some explanation for the rising rates of asthma and allergies; however, researchers acknowledge they need to know much more about both sides of the equation. - Ann Silversides, Toronto

DOI:I0.1503/cmaj.070404

\section{UK doctors may lose}

\section{self-regulation}

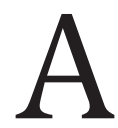
proposal from the United Kingdom Department of Health could bring an end to the era of professional self-regulation for doctors and other health professions by 2008 .

A Department spokesman said the question of self-regulation arose in response to the Harold Shipman Inquiry (CMAJ 2003;169:46I); several other high-profile cases; and the Chief Medical Officer's review of medical regulation, Good Doctors, Safer Patients (July 2006). The Department has now published its white paper: Trust, Assurance and Safety: The Regulation of Health Professionals in the 2Ist Century.

Parliament must pass a Bill before the proposals come into effect; to date the bill has not even been tabled.

The General Medical Council (GMC), charged with protecting the public and ensuring proper standards in medicine, submitted its proposal for change to the government in November 2006. "Regulation has been surrounded by controversy for the past decade, a situation that is not good for either public or professional confidence," Chief Executive, Finlay Scott told CMAJ.

If the proposal is approved, the regulators will be independent of government, and will consist of an equal partnership of professional and lay members. The aim is to ensure that purely professional concerns do not dominate the proceedings, and to dispel the notion that regulators are overly sympathetic to the medical profession.

According to Scott, self-regulation, has served patients and the public well but is no longer credible, and no such scheme would command public or political support in today's climate.

Under the proposal, doctors will have to revalidate their license to practise every 5 years to meet standards set and assessed by the Royal Colleges. The Royal College of Physicians says it welcomes this role in setting clinical standards for medical practice. "We have decades of experience to draw on, and have been in the forefront of developing new methods of continuing assessment for doctors," says its President, Professor Ian Gilmore.

The proposed changes will also alter the onus of proof at disciplinary hearings from the criminal standard, wherein facts must be proven beyond reasonable doubt, to a civil standard that requires that the facts be judged more likely than not to be true. The latter is already employed by most health regulators. A Department of Health spokesman explains that "The public are unable to understand why a disciplinary hearing by a National Health Services employer can find a practitioner guilty of misconduct but the regulatory body then states that there is not enough high quality evidence for a hearing to consider their registration."

Scott made it clear that for the most serious matters, such as those that could lead to loss of registration, the effect of the civil standard of proof will, in practise, be close to the existing criminal standard.

The British Medical Association has concerns with the proposal. "Removal of the adjudication function from the GMC, having appointed GMC Council members instead of elected doctors, lay and medical members, and the switch to a lesser burden of proof for fitness to practice, all add up to a loss of professionally led regulation." However, a Department of Health spokesman emphasized that the new system will be predominantly professionally led, with doctors carrying out appraisal, setting and assessing standards, and sitting on the adjudicating panels.

The GMC hopes the plans for professional and lay regulatory bodies will be implemented in the latter half of 2008 , along with the move to the civil standard of proof. This will be followed by pilot revalidation schemes in 2009, with full implementation during the following year.

In Canada, the President of the Federation of Medical Regulatory Authorities, François Gauthier, says that like the proposed UK system, "all Canadian jurisdictions have public or non-physician representatives, and in several cases, some or all of these are government appointees." - Cathel Kerr, Fife, Scotland

DOI:I0.I503/cmaj.07043I

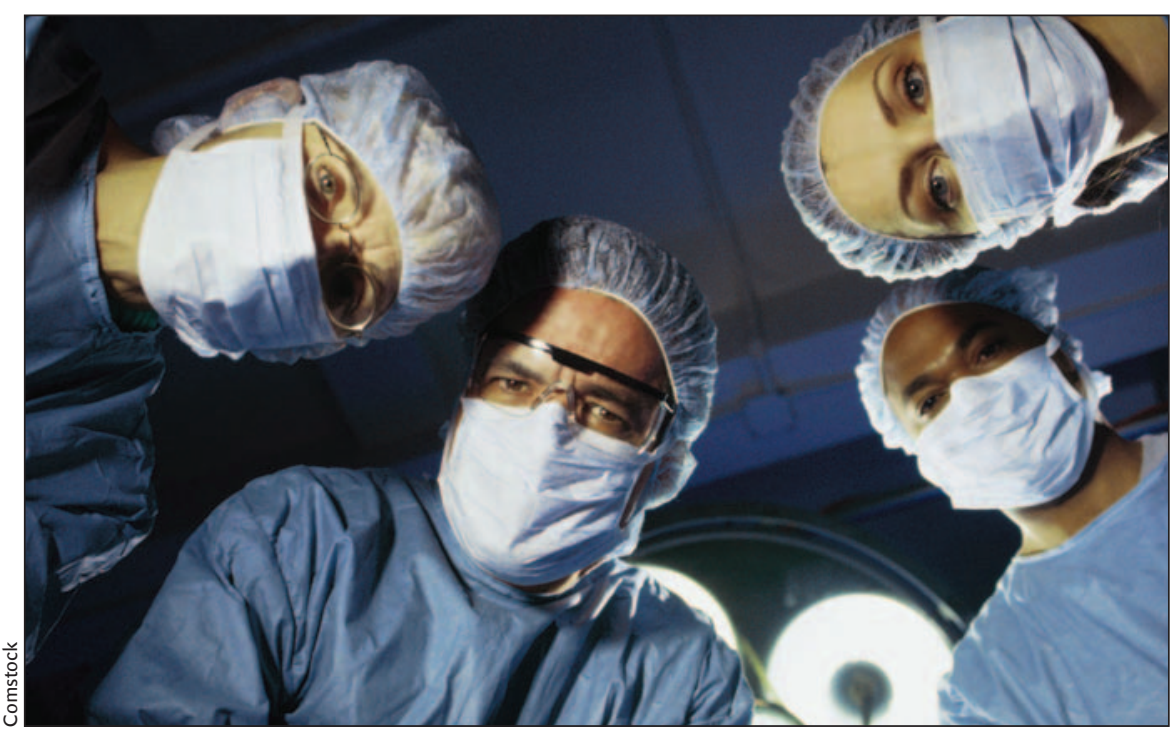

The UK's General Medical Council says self-regulation is no longer a credible option. 